\title{
Michael Malim
}

Long after others had given up, Michael Malim stayed in dogged pursuit of a protein that can stop HIV in its tracks. On the way to success, he also managed to make his colleagues laugh.

When you first meet Michael Malim, you might think he is reserved. Malim, who is credited with one of the most important discoveries in HIV research of the past decade, has that rather English demeanor that seems part shy, part standoffish. But don't be fooled. Notice the James Bond 007 watch, the footwear that proclaims 'Big Bad Mike's Socks', then wait for the deadpan one-liners that are sure to follow.

Malim is one of a group of HIV researchers - many of them Britishwho play puerile practical jokes on each other, some of which have involved mattresses dragged into bathtubs, hidden alarm clocks set to go off in the middle of the night and autoradiographs slipped into sandwiches.

"Mike just comes across as such a scholarly gentleman but when you get to know him better, you realize that's not true," says Mario Stevenson, professor at the University of Massachusetts in Worcester. "He's neither scholarly, nor a gentleman —which is why I like him so much."

When it comes to research, however, Malim is all seriousness. His most famous work, which graced the cover of Nature in July 2002, identified an elusive human enzyme that HIV must overcome in order to survive in the body. That was the proof that HIV has to actively defend itself, a concept that could lead to new therapies. It has also spawned dozens of papers on APOBEC 3G, the host defense factor, and inspired optimism in the field. "It's such an important, almost revolutionary achievement," Stevenson says. "It's changed the way we think about viruses like HIV."

Less famous is Malim's recipe to arrive rested after transatlantic flights: three beers on the flight and two after landing. "Not only has Mike given us the fundamental insights into host cell-virus interaction, but he's cured jetlag," says friend and collaborator Steve Wolinsky of Northwestern University. "Mike has always been one to think out of the box."

Malim grew up in southern England, a regular thorn in his teachers' sides, and says he probably became interested in science because it was the only subject where he was allowed to stay in class. He completed his D. Phil. at Oxford University, where he also played golf for the varsity team, then arrived at Duke University in 1987 to begin a postdoctoral fellowship.

During his five years there, Malim published 25 papers, 10 of them first-author papers, including two in Nature, three in Cell and two in the Journal of Experimental Medicine. "Mike was extremely organized, always working on four or five projects simultaneously," says Bryan Cullen, Malim's postdoctoral mentor. "There wasn't a lot of standing around drinking coffee, bullshitting about the Duke basketball team or whatever."

Cullen recalls one incident when Malim had run experiments using the last of some precious samples. The resulting nitrocellulose filter was drying in a hot vacuum oven when a student from a neighboring lab, despite all the warning signs on the oven, let air rush in. The fragile filter got blown into the side and smashed to pieces. "That's the only time I ever saw Mike hit the roof," Cullen says. "He was f-ing and f-ing up the corridor and jumping up and down. Other than that, he's a really equable, even-tempered guy."

What Cullen doesn't know, however, is that Malim hybridized the broken filter in little bits, painstakingly pieced it back together and exposed it to film. "All was not actually lost in the end, except for a vast amount of time," Malim says. Still, most of his time was well spent. Even without applying, he got job offers from the University of California in San Francisco, Harvard University and the University of Pennsylvania. When Malim was trying to make a decision, Neal Nathanson, then head of the microbiology department at Penn, called Malim and traded recipes for soufflés for 20 minutes. By the time he hung up, Malim, an avid cook, was sold.

Six years on, after Penn had granted Malim tenure, the Howard Hughes Institute, which had funded Malim for those years, terminated his grant. "Mike was upset by that, and frankly, they screwed up, they really made a mistake," says Nathanson. Malim says he had been expecting not to be renewed. Like most of his colleagues, the reviewers didn't believe then that his approach to finding the defense factors would succeed. "Had I been reviewing me at that time in 1998," he says, "I would probably have done the same thing."

A year later, London came a-calling: Malim was offered the chance to head a new department of infectious diseases at King's College London. At the time, Malim was fully settled at Penn. "I was completely Americanized, I was shouting at everyone for not working hard enough," he says. But the offer was too good to pass up, so he and his wife, geneticist Rebecca Oakey, left their friends - and his purple pickup truck-behind and returned home. Now, he says, "I spend my time working on why the toilets don't work."

At the time of his move, Malim was trying to find the elusive host defense factor that the HIV protein Vif must overcome. Based on experiments he had published in 1998 (Nat. Med. 4, 1397-1400; EMBO J. 17, 1259-1267), he was convinced that the factor must exist. "We'd been fiddling around with Vif for donkey's years with little success," he says. "I don't get put off by things that are difficult, that's for sure."

"We'd been fiddling around
with Vif for donkey's years
with little success. I don't
get put off by things that are
difficult, that's for sure."

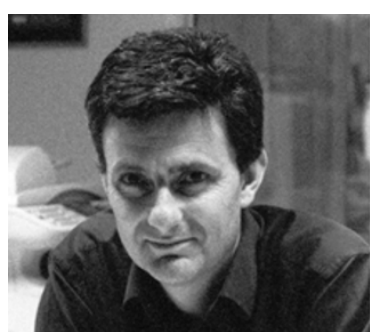

When postdoctoral fellow Ann Sheehy began narrowing down candidates for the elusive defense factor, APOBEC3G - or CEM15 as she dubbed it then — was one of the first candidates she found in late 1999, but it only appeared in the sequence databases more than a year later. Sheehy finally cloned the gene in late 2001 and found that it dramatically inhibited HIV infection in the absence of Vif. "She pulled off a phenomenal piece of work basically single-handedly," Malim says. "I hadn't done anything worthwhile except stay out of her way so she could get on with it."

The data looked so clean that a skeptical Sheehy repeated the experiment several times, re-prepped the DNA, then got somebody else to do it. Because Malim has little faith in fast kits that have replaced the labor-intensive classical techniques, all the experiments had to be done the "hard-core oldfashioned way," Sheehy says. Finally convinced, they decided to present the data at the 2002 Conferences on Retroviruses and Opportunistic Infections (CROI) in Seattle. "This was going to be this huge splash, we knew it would get a lot of attention, and Mike let me present," she recalls.

Three years on, at this year's CROI meeting, Malim was asked to give the prestigious Bernard Fields Lecture. But attendees were treated to an unexpected glimpse of tomfoolery when Stevenson introduced him with a picture of Malim in a hot tub, holding a glass of wine. Malim says he was thrown for a loop by the introduction, but quickly regained his composure. And so begins another round of practical jokes. "I'm going to get [Stevenson] back," Malim says. "I'll bide my time. No need to rush into it."

Apoorva Mandavilli, Banff 